\title{
Fire and climate: Biomass burning recorded in ice and lake cores
}

\author{
N. Kehrwald ${ }^{1}$, R. Zangrando ${ }^{1}$, A. Gambaro ${ }^{1,2}$, and C. Barbante ${ }^{1,2}$ \\ 1 Institute for the Dynamics of Environmental Processes - CNR, University of Venice, Dorsoduro \\ 2137, 30123 Venice, Italy \\ 2 Department of Environmental Science, University Ca' Foscari of Venice, Dorsoduro 2137, 30123 \\ Venice, Italy
}

\begin{abstract}
Human activities including fossil fuel burning are currently altering the global climate system at rates faster than ever recorded in geologic time. Biomass burning causes carbon dioxide emissions equal to 50\% of those from fossil-fuel combustion and so are highly likely to influence future climate change. However, aerosols continue to be one of the least understood aspects of the modern climate system and even less is known about their past influence. Ice and lake core proxy records provide quantifiable data on past fire regimes across most spatial and temporal scales. Some monosaccharide anhydrides such as levoglucosan, mannosan and galactosan are used as specific molecular markers for biomass burning as they can only be produced by combustion processes at temperatures greater than $300^{\circ} \mathrm{C}$ and are present in both ice and lake cores. Other paleofire tracers such as microcharcoal, polycyclic aromatic hydrocarbons, and pollen records augment the fire history derived at single sites or across regions. As both pyrochemical and climate parameters are determined from the same depth and time within the ice or sediment matrix, the multi-proxy nature of ice and lake cores presents an ideal material to investigate the links between fires and climate change.
\end{abstract}

\section{Introduction}

Fire is one of the major influences of ecological change on local to hemispheric scales. Fires affect the global carbon cycle through changing vegetation distribution, primary productivity, biodiversity, and atmospheric chemistry. Biomass burning caused by current human activities emits up to $50 \%$ as much carbon dioxide as fossil-fuel combustion [1] and is therefore highly likely to influence future climate change. Ice and lake cores contain specific molecular markers and other pyrochemical and palynological evidence which provides much-needed information on the role of fire in driving past climate and the possibility of current biomass burning affecting future global climate.

Sedimentary charcoal records and modern satellite observations demonstrate global fire activity in relation to atmospheric carbon dioxide, the appearance and dispersal of humans, the presence of major vegetation regimes, and natural climate cycles [1-3]. Micro-charcoal records depict hemispheric relationships in paleo-fire activity on millennial timescales $[4,5]$ which are caused in part by regional to global climate controls as well as local vegetation and fuel load changes regardless of human activity $[1,2]$. Historical meteorological data depict the dominance of climate in large regional fires $[1,6]$ and observational analyses show the coupling between fires and interannual- to decadal-scale climate oscillations $[1,7]$. Human activities can and have altered fire activity beyond background climate conditions

This is an Open Access article distributed under the terms of the Creative Commons Attribution-Noncommercial License 3.0, which permits unrestricted use, distribution, and reproduction in any noncommercial medium, provided the original work is properly cited. 
as long ago as the late Pleistocene [8] and have significantly changed vegetation regimes with changing agricultural and pastoral practices [9].

Fires influence climate by releasing atmospheric aerosols that provide cloud condensation nuclei and increase atmospheric water vapor [10]. Organic aerosols comprise up to $90 \%$ of the submicron particulate mass $[11,12]$ in the released burning products). Biomass burning aerosols have a significant anthropogenic component with a significant direct radiative forcing [13]. The current estimates for biomass burning-related aerosol radiative forcing are not well-constrained and defined as $+0.03( \pm 0.12)$ $\mathrm{W} \mathrm{m}^{-2}$ [13]. The total global emission of black carbon from biofuel combustions is estimated as $3.3 \mathrm{TgC}^{-1}$ from open biomass burning, with an uncertainty factor of two ${ }^{8}$. Up to $65 \%$ of the variability in the carbon dioxide growth rate between 1997 and 2001 is ascribed to biomass burning [2]. Climate may have influenced the fire activity during this period as ENSO-related droughts resulted in widespread landscape burning [2]. Conversely, the global increase in greenhouse gases and the associated warming amplify the likelihood of fire activity [2,13]. The net climate impacts and radiative forcings of aerosols are complex because the mixing of particles with other aerosols changes their sizes and chemical composition which influences further aerosol formation or removal $[1,13,14]$.

Ice and lake core records provide quantifiable data on past fire regimes on millennial to seasonal time scales. Chemical markers of past fires recorded in ice cores include monosaccharide anhydrides (MAs) such as levoglucosan, mannosan and galactosan, light carboloxic acids (oxalates, formate, and acetate), polycyclic aromatic hyrocarbons (PAH), and lignin burning products [15-17]. Sediment core studies of past fires primarily use charcoal counts as a paleofire indicator[18] and are supplemented by studies investigating PAH or MAs [19]. Here, we investigate the use of MAs including levoglucosan as a specific tool in paleofire reconstruction because of their applicability to both ice and lake core studies. Levoglucosan (1,6-anhydro- $\beta$-D-glucopyranose) is a globally pervasive molecular tracer for atmospheric biomass burning which can only be produced by burning woody tissue [20,21]. As both levoglucosan and climate parameters are measured from the same depth and time within the ice or sediment matrix, the multi-proxy nature of ice and lake cores presents an ideal material to investigate the links between fires and climate change.

\section{Biomass burning tracers}

\subsection{A fire tracer present in both ice and lake cores: Levoglucosan}

Biomass burning injects particles with adsorbed biomarker compounds into the global atmosphere [22]. Flammable vegetation leaves distinct signatures of organic matter associated with particles in smoke where smoke is defined as small gas-borne particles formed during incomplete combustion. Important compounds from biomass burning include MAs, and the most important tracer compound among them is levoglucosan (1,6-anhydro- $\beta$-D-glucopyranose) and to a lesser degree galactosan $(1,6-$ anhydro- $\beta$-D-galactopyranose) and mannosan (1,6-anhydro- $\beta$-D-mannopyranose). Molecular markers such as MAs are important tools in tracking the transport of particles produced by biomass burning because they are only generated by combustive processes. Levoglucosan determination does not depend on the combustion continuum where combustion products are compared to a spectrum of uncharred biomass to graphite depending upon burn duration and combustion temperature. Instead, levoglucosan and other MAs are unambiguously degradation products from cellulose formed at temperatures greater than $300{ }^{\circ} \mathrm{C}$ [22]. Among MAs, levoglucosan has been considered an excellent choice because it is emitted in large quantities, is source specific, and is globally pervasive [21,22].

Until recently, levoglucosan was assumed to be stable in the atmosphere based on air filter and acidic solution studies [23,24]. Locker [23] investigated the atmospheric stability of levoglucosan in ambient conditions by spiking filters with known concentrations of levoglucosan and exposing the filters to up to 8 hours of sunlight. The levoglucosan did not degrade, and Locker concluded that levoglucosan can be used as a marker compound. Fraser and Lakshmanan [24] and later Simoneit et al. [25] examined the acid-catalyzed hydrolysis of levoglucosan and determined that levoglucosan was stable in the atmosphere for at least 10 days, even in acidic conditions. However, recent studies have examined the assumption that levoglucosan is inert in the atmosphere. Holmes and Petrucci [26,27] outline 
reactions between $\mathrm{OH}$ radicals and levoglucosan to form higher molecular weight compouds under atmospherically relevant conditions. Field studies [28] compare seasonal levoglucosan with potassium ion $\left(\mathrm{K}^{+}\right)$concentrations, where $\mathrm{K}^{+}$is assumed to be another tracer for biomass burning emissions. The higher levoglucosan to $\mathrm{K}^{+}$ratios in the winter suggest that levoglucosan may oxidize with more readily available $\mathrm{OH}$ in the summer, resulting in the degradation of levoglucosan [29]. Typical summer $\mathrm{OH}$ levels cause degradation of levoglucosan in biomass burning plumes and therefore levoglucosan should be used in conjunction with other chemical indicators [30]. However, Holmes and Petrucci [26] note that although chemical processes may remove levoglucosan from biomass burning smoke, the chemical transformations of levoglucosan in the smoke plume generate secondary tracers that provide information on the age and source of the aerosol parcel. While a percentage of levoglucosan does degrade in smoke plumes, the high concentration of levoglucosan emissions suggests that levoglucosan is a viable tracer for biomass burning [26,27].

The strength of using levoglucosan as a recorder of past fire activity lies in its specificity and its availability in many continental proxies. However, a more robust analysis of fire history can be achieved by combining and comparing levoglucosan flux with measurements of other chemical indicators or pollen assemblages. The following sections detail other available biomass burning proxies and fire histories reconstructed from ice and lake cores.

\subsection{Fire tracers present in ice cores}

\subsubsection{Black carbon}

Annually, 8.2 Tg of black carbon (BC) is emitted to the atmosphere [30] as a by-product of incomplete combustion of various fuel types from contemporary (e.g. wood) or fossil (e.g. coal) carbon sources, and during wildfires and prescribed burns. Black carbon, which is also sometimes referred to as elemental carbon (EC), is an end member of the atmospheric carbon spectrum that ranges from uncharred biomass to graphite [18]. Black carbon is comprised of graphitic substances including soot and originates from direct particle emissions [18]. This definition differs from that of organic carbon (OC) which is primarily comprised of polyacidic hydrocarbons and can be either a primary or secondary organic aerosol emitted from natural biogenic sources [18,31].

The general assumption is that the main form of $\mathrm{BC}$ in ice cores is soot, however, other forms of $\mathrm{BC}$ such as charcoal or kerogen may be eroded by wind from soils and sediments and transported to ice fields as mineral dust particles $[31,32]$. The majority of $\mathrm{BC}$ is a sub-micron aerosol and therefore can be transported across hemispheric distances. Black carbon is exclusively produced by incomplete combustion, but the combustion source can either be biomass or fossil fuels. The combustion source can be determined by examining the ${ }^{14} \mathrm{C} /{ }^{13} \mathrm{C}$ ratio of the $\mathrm{BC}$, where modern levels of ${ }^{14} \mathrm{C}$ suggest a biomass source, while the absence of ${ }^{14} \mathrm{C}$ suggests a fossil fuel source [31,32]. Up until approximately 1950 AD wildfires dominated global black carbon emissions, with prescribed fires and biofuel burning playing a minor role. Between 1950 and 1990 AD, global black carbon emissions from fossil fuel

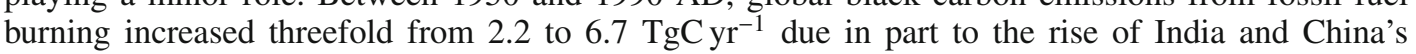
economies [33]. The percentage of BC produced by fossil fuel versus biomass burning is expected to continue increasing in the future.

\subsubsection{Polycyclic aromatic hydrocarbons}

Polycyclic aromatic hydrocarbons (PAH) are ubiquitous pollutants from fossil fuel or biomass incomplete combustive processes and are considered "priority pollutants" by the US Environmental Protection Agency (EPA) [34]. These pollutants are transported over global distances by wind systems [17] and are archived in both polar and mountain glaciers. PAH have been determined in ice core studies from Greenland [35,36] and the Himalaya [37]. Approximately 90\% of recent PAH emissions derive from anthropogenic sources [17], and so ice core records primarily depict the historical environmental burden of PAH as a consequence of human activities. Preindustrial quantities of these compounds in ice cores are very low and have mean concentrations in the range of $0.08 \mathrm{ng} / \mathrm{kg}$ to 
$0.2 \mathrm{ng} / \mathrm{kg}$ [17]. Wildfires comprise the largest PAH input from natural combustion but the compounds are not source specific. Wood, coal, and grass burning can be differentiated from gasoline, diesel, and crude oil combustion based on the ratios of flouranthene (Fla) to flouranthene plus pyrene (Pyr) (Fla/ $(\mathrm{Fla}+\mathrm{Pyr}))[17]$. This ratio helps differentiate between biomass burning versys hydrocarbon combustion, but coal burning is included with the wood and grass burning, and so a specific wildfire source cannot be determined. However, greater specificity regarding the organic materials being burned can be obtained through analyzing vegetation sources as outlined in the following section.

\subsubsection{Aromatic alcohols}

Recent advances in methodology now allow the determination of major species of burned vegetation in smoke particles, and these techniques can be applied to paleorecords [18]. Source specific molecular tracers not only show that fires occurred, but also provide a chemical fingerprint which can be used to identify past regional vegetation cover [22]. The three major plant classes of grasses, softwoods, and hardwoods contain differing proportions of three major aromatic alcohols where grasses are enriched in p-coumaryl alcohol, softwoods contain primarily coniferyl alcohol, and hardwoods include a high proportion of siapyl alcohol. Therefore, burning vegetation produces degradation products in proportion to different types of biomass [39]. Smoke from burning softwoods injects relatively large quantities of aromatic alcohols into the atmosphere. These higher atmospheric concentrations result in softwoods being the easiest plant class to determine through the analysis of its degradation products. Hardwoods and grasses produce significantly less oxygenated compounds from aromatic alcohols, to the point where these compounds are almost undetectable in grass smoke [22]. The determined aromatic alcohols can then be compared to levoglucosan concentrations to examine the relative contribution of each vegetation type to the resulting smoke plume.

\subsubsection{Light carboxylic acids}

Direct emissions of biomass burning inject organic acids including formate $\left(\mathrm{HCOO}^{-}\right)$, acetate $\left(\mathrm{CH}_{3} \mathrm{COO}^{-}\right)$and oxalate $\left(\mathrm{C}_{2} \mathrm{O}_{4}^{2-}\right)$ into the global atmosphere. These acids have been measured in polar ice and provide a record of past forest fires for up to a complete glacial-interglacial cycle $[15,38]$. Marine and continental biological processes are the primary contributors of the carboxylic acids, where biomass burning contributes up to 30\% of the total measured in Greenland ice [38]. Studies of carboxylic acids in snow and ice have been conducted since the late 1980s [39] and demonstrate significantly higher concentrations of carboxylic acids in the past 10,000 years than during the last glacial maximum (LGM) [40]. This increase in carboxylic acid concentrations during the Holocene is from both increased primary productivity and the contribution of high-latitude vegetation burning [40]. Large increases of formate in ice core records are associated with peaks in ammonium concentrations, where ammonium may also be used as a tracer of biomass burning. This correspondence suggests that tandem peaks of formate and ammonium concentrations may be caused by past forest fires [39].

The relatively long history of determining carboxylic acids in ice means that oxalate and other light carboloxic acid analyses can be used to calibrate the two types of measurements. Oxalate and levoglucosan concentrations in sixty-eight snow pit samples from near Summit, central Greenland $\left(72^{\circ} 20^{\prime} \mathrm{N} ; 38^{\circ} 45^{\prime} \mathrm{W} ; 3270\right.$ masl) are depicted in Fig. 2 . The sodium $\left(\mathrm{Na}^{+}\right)$measurements define the strong seasonality at this site, and determine the age scale. The oxalate peaks in summer 1994 that is an order of magnitude higher than neighboring samples and is attributed to emissions from a Canadian forest fire [17]. The levoglucosan flux replicates the oxalate measurements in the Greenland snow samples (Fig. 2), suggesting that the two types of measurements can be used in tandem to provide more robust results of past biomass burning. Oxalate can be produced by multiple pathways including metabolic processes by fungi and vehicle emissions while levoglucosan is a much more specific organic biomarker as previously outlined in this chapter [16]. The established history of determining light carboxylic acids in ice cores and the specificity of MAs such as levoglucosan provide complimentary techniques for paleofire reconstruction. 


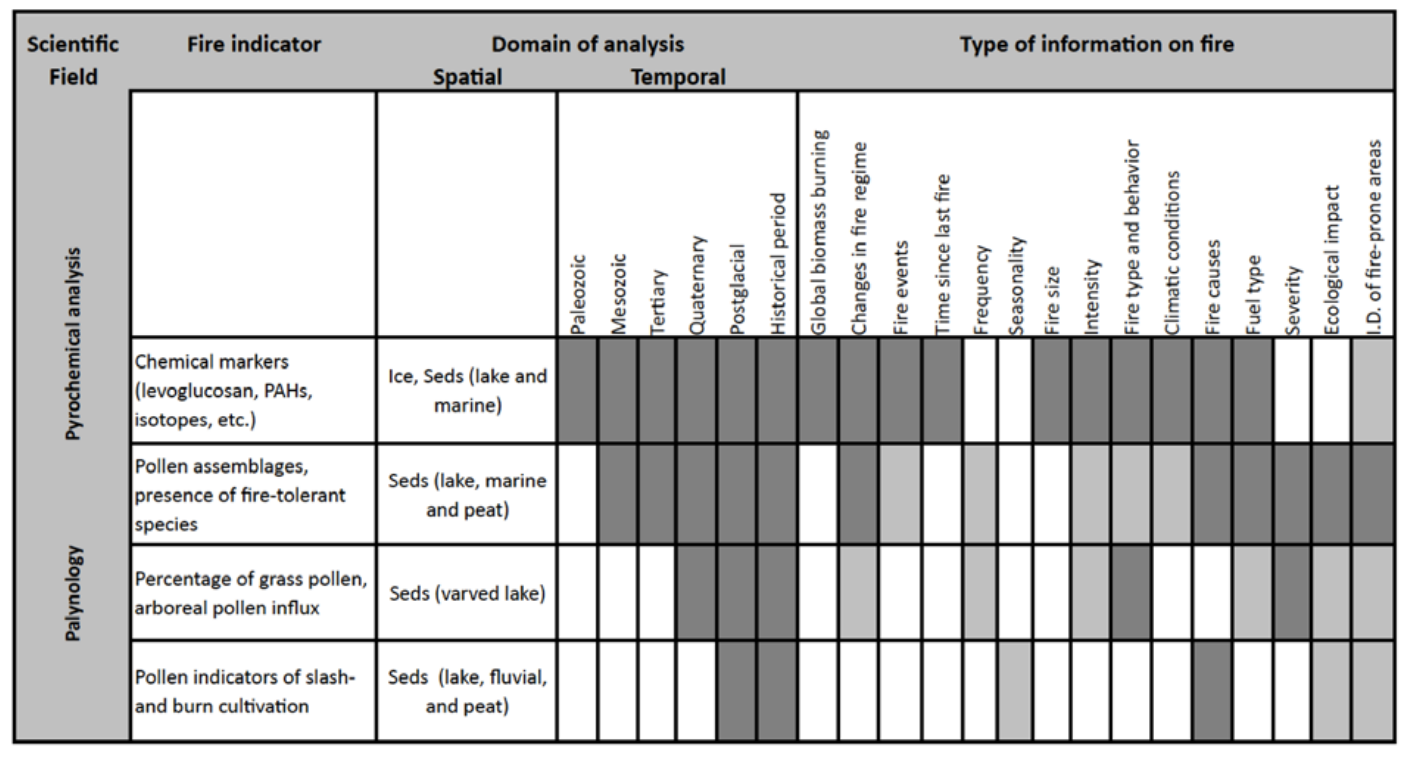

Fig. 1. The typical spatial and temporal reach of chemical markers and palynological evidence for past fire regimes (modified from Conedera et al., 2009). The dark gray markers depict high reliability and the light gray markers indicate interm ediate reliability. Time periods are: Paleozoic (250-540 Myr); Mesozoic (85-250 Myr); Tertiary (2-65 Myr); Quaternary (15,000-2 Myr); Postglacial (2000-15,000 yr); Historical period (0-2000 yr).

\subsection{Fire tracers present in lake cores}

\subsubsection{Charcoal}

The most comprehensive information that is currently available about past fire activity is derived from charcoal records in lake cores. Charcoal is a direct indicator of past fire which is produced by the incomplete combustion of organic matter [18]. Lacustrian charcoal records are primarily from the approximately the past 15,000 years and so provide post-glacial and Holocene records of fire activity, although a few records span the entire Quaternary (18 and references within). The spatial extent of climate information derived from sedimentary charcoal records fan range from a local signal (within or neighboring a watershed) up to a global signal.

All charcoal determination methods use particle size distribution to determine if the particles are the result of a local, regional, or global source. Large particles between 100-200 $\mu \mathrm{m}$ are assumed to reflect regional fire 918 and references within). Local fires are defined as occurring within a few 100 meters from the lake basin, while regional fires comprise an area of $100 \mathrm{~s}$ of meters from the watershed [18]. While charcoal represents past fire events, sometimes secondary charcoal deposition in lake sediments can cause time elapses. For example, charcoal that was deposited on neighboring hillsides after a fire may be re-suspended and flushed and deposited into a lake after a large precipitation event [1].

The resolution of the resulting fire and climate record depends both on the sedimentation rate the sampling procedure. Varved sediments provide the most precise data, but must be sample contiguously to provide an annual high-resolution record. The minimum sampling size needed for a robust measurement is usually $2 \mathrm{~cm}^{3}$, and sampled at least each centimeter down-core [18]. Such sampling leads to mean resolutions of decadal-scale measurements.

\subsubsection{Pollen}

Pollen reconstructions from lake sediment cores can provide essential information on past fire regimes on timescales reaching back as far as the Mesozoic (65-250 million years before present) as shown in Fig. 1 [18]. Of the available palynologic techniques, far and away the most common approach is the 


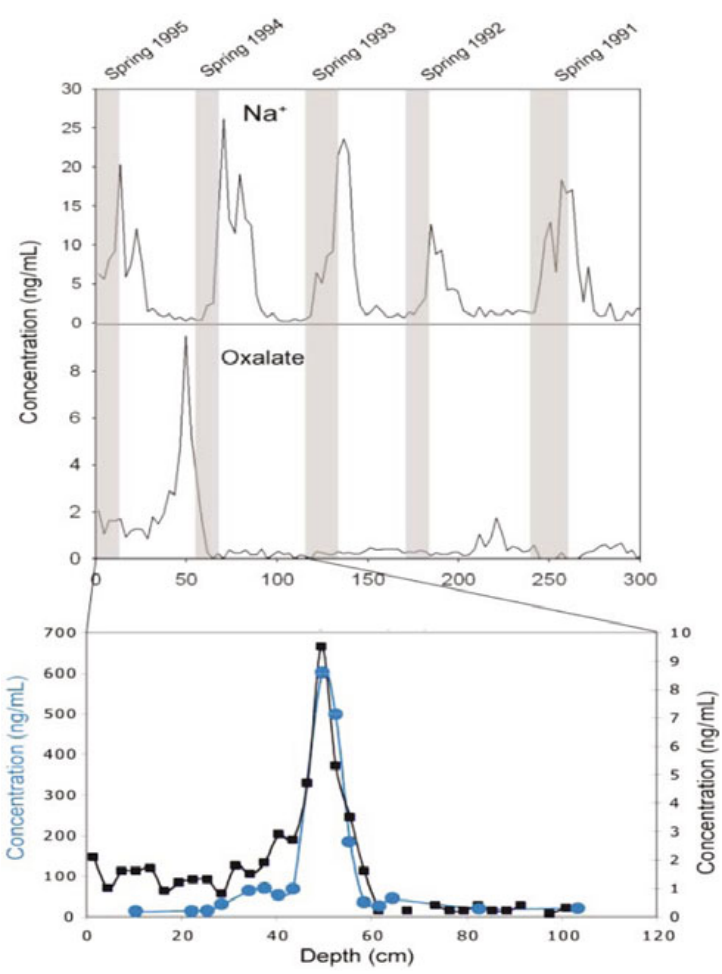

Fig. 2. Changes in $\mathrm{Na}^{+}$and oxalate concentration averaged from 68 central Greenland snow-pit samples from the surface (June 1995) to $270 \mathrm{~cm}$ (1991). Peaks in $\mathrm{Na}^{+}$are associated with boreal winters as increased cyclogenesis in the North Atlantic deposits greater concentrations of sea salts on the Greenland Ice Sheet. Gray bars indicate the position of spring snow accumulation. The upper section of the figure is modified from [17]. The lower section of the figure depicts levoglucosan concentrations (gray/blue cycles) measured in 2009 from the same samples as the oxalate peak (black squares) and demonstrate the fire signal was recorded in two separate tracers.

analysis of pollen assemblages. In this technique, pollen types are identified on slides under an optical microscope, and the relative percentages of each pollen species are determined. The compilation of pollen types can identify the ecosystem, and establish any changes in vegetation such as the departure from a heavily forested area to a grassland dominate region. Palynology an also identify the presence of fire-tolerant species. In addition, palynological analyses are among the few measurements than can be used to directly determine a human impact on climate. Pollen indicators provide information on the present of slash-and-burn cultivation [18]. The anthropogenic pollen indicator provides information on human disturbance of ecosystems, primarily in regards to agricultural activity [41]. Pollen indicators are extremely useful in determining the available vegetation types, but the investigation of pollen in fire reconstruction should always be used in conjunction with another paleofire indicator since many non-fire impacts such as wind, floods, and landslides may influence the pollen deposition and therefore influence the paleoenvironment reconstruction [18].

\section{Fire history recorded in lake cores}

Hundreds of lake sediment records are compiled in the global charcoal database, which catalogues macroscopic and microscopic charcoal data and associate lake core chronologies in a publiclyaccessible database. Power et al. [1] synthesized 355 terrestrial charcoal records into 1000-year timeslice maps to analyze regional and global changes in biomass burning since the LGM approximately 21,000 years ago. All analyzed records were compared to a pre-industrial baseline. Sites near ice sheets during and after the LGM, such as North America, Europe, and Patagonia show decreased fire 
activity between 21,000 to approximately 11,000 years BP [1]. Although the time-slice maps show spatial variability across continents, the majority of sites demonstrate fire activity greater than or equal to that of the present through the duration of the Holocene. During the maximum Asian monsoon activity between $~ 6000$ to 8000 years before present, sites in Eastern Asia, Indonesia, and Australia record decreased fire activity [1] which suggests that the increased precipitation may have dampened fire activity, even with the increased vegetation as potential fuel. Changes in regional climate appear to be the prominent control on fire activity over the analyzed 1000-year time scales [1] but highresolution lake cores may provide more detailed information on the influence of climate change and human activity on biomass burning.

Lake sediments in Central Europe and Eastern Africa demonstrate direct linkages between fire and human activity [42]. A Lake Lucerne, Switzerland lake core documents major increases in locallyderived coarse-fraction $(>38 \mu \mathrm{m})$ charcoal which corresponds with the Middle/Younger Neolithic transition (5550 yr BP), the Early/Late Bronze Age transition (3300 yr BP), and the First/Second Iron Age transition (2400 BP) [43,43]. Globally, these periods also correlate with times of general cooling, and regionally, coincide with times of unstable climate [44]. A major large-fraction charcoal peak also occurs from approximately $150 \mathrm{yr}$ BP until the present day and directly corresponds with regional industrialization [42]. A Lake Masoko core from southern Tanzania $\left(9^{\circ} \mathrm{S}, 33^{\circ} \mathrm{E} ; 770\right.$ masl) demonstrates a steady state in fire activity between 4000 to $2000 \mathrm{yr}$ BP, with a marked increase in all charcoal size fractions at $1800 \mathrm{yr}$ BP (Thevenon et al., 2010). These charcoal peaks coincide with regional forest clearing associated with Iron Age activities [42,45]. Correlating lake sediment records to anthropogenic fire activity requires decadal resolution records and either a steady-state natural signal or multiple proxies that help explain the contribution of climate to the fire record. Lake cores provide an excellent archive for examining the linkages between climate, fire, and human activity.

\section{Fire history recorded in ice cores}

The study of past fire activity using ice core records opens regions of the world where no paleofire data previously exited. Polar and low-latitude, high-altitude ice cores provide data for regions which are not represented in the global charcoal database. The available temporal resolution matches that of the ice core, with the longest temporal resolution being that of the EPICA Dome C ice core that extends back approximately eight glacial cycles [46]. The spatial resolution of chemical markers in ice cores depends on the location of the core itself. Low-latitude ice cores primarily reflect regional climate parameters, while polar ice cores reflect a global signal. The fidelity of the information gleaned from ice core records is dependent upon the core quality as well, where post-depositional processes such as melt, extreme wind scour or internal ice flow dynamics can alter the quality of the measured proxy. The field of reconstructing fire histories from ice cores is still in its initial stages, however, the huge available archive and global array of ice cores easily allows for future research into one of the least known aspects of the climate system.

Studies have used potassium ions $\left(\mathrm{K}^{+}\right)$and ammonium $\left(\mathrm{NH}_{4}^{+}\right)$[47-49] in ice cores as indicators of past fire activity. Both $\mathrm{K}^{+}$and $\mathrm{NH}_{4}^{+}$are regularly measured as part of the standard suite of major ions are so are often available records used as an approximation of paleofires. Ammonium is initially emitted as ammonia $\left(\mathrm{HN}_{3}\right)$ in the atmosphere [49], and can be produced by lighting, and so may represent a natural ignition source for wildfires, but a major source of these ions in the atmosphere is agricultural activity including the use of fertilizers. Kekonen et al. [50] present a 800-year of nitrate and ammonium from an ice core in Svalbard and conclude that the major changes in both reflects twentieth-century anthropogenic input. Eichler et al. [48] construct past fire history in a Siberian ice core using $\mathrm{K}^{+}$and charcoal concentrations to determine that the peak regional fire activity occurred between 1600 and $1680 \mathrm{AD}$ after an extended dry period, and therefore the biomass burning has a natural rather than anthropogenic source. These major ion studies can be supplemented in the future by specific molecular markers, as outlined in section 2.2 . As levoglucosan can only be produced by the burning of woody tissue at temperatures of $300^{\circ} \mathrm{C}$ or greater, this biomarker therefore provides insight into both past fire intensity and the general vegetation type. These specific markers may help to differentiate between the percentage of $\mathrm{K}^{+}$and $\mathrm{NH}_{4}^{+}$that are caused by biomass burning and the fraction that is attributable to agriculture or other land-use changes. 
One aspect of fire history in ice cores that has recently been the subject of multiple studies is the analysis of $\mathrm{BC}$ in ice cores $[31,37,51]$. BC measurements in a Greenland ice core demonstrate a link between recent industrial $\mathrm{BC}$ emissions and twentieth-century warming [51]. The Arctic warming is attributed in part to the absorbing properties of $\mathrm{BC}$ [51] and thus provides a link between ice and combustion products. The percentage of $\mathrm{BC}$ derived from biofuel burning can be determined by examining the ${ }^{14} \mathrm{C} /{ }^{12} \mathrm{C}$ ratios of $\mathrm{BC}$ extracted from the ice [31]. Such source apportionment studies are especially exciting in the Himalaya where the hypothesis that rapid glacier retreat is caused by $\mathrm{BC}$ deposition on snow surfaces is actively being analyzed [52]. Ming et al. [37] measured BC concentrations in a Mt. Everest ice core for the past 50 years and determined that $\mathrm{BC}$ from South Asian emissions are reaching the high Himalayan peaks. Although ${ }^{14} \mathrm{C} /{ }^{12} \mathrm{C}$ ratios can differentiate between fossil fuels and biomass, much of the modern carbon is derived from the use of biofuels for cooking or other household activities rather than through landscape fires. The momentum behind BC studies in ice cores suggests that more combustion (biofuels, biomass, and fossil fuels) histories will soon be available in the literature.

\section{Application of fire records to discern human impacts on global climate change}

A global array of ice and lake cores allows for ongoing direct investigations into discerning regional or global increases in fire associated with the timing of the advent of agriculture. A recent provocative hypothesis by Ruddiman [53-55] suggests that humans may have had a significant impact on the Earth's climate thousands of years ago through carbon and methane emissions originating from biomass burning and deforestation associated with early agriculture [53-55]. This hypothesis is centred on the observation that atmospheric carbon dioxide and methane levels were at their minima approximately 7,000 to 5,000 years before present, respectively, and then slowly increased until the rapid rise in greenhouse gases (GHGs) caused by the Industrial Revolution [53-55]. The increase in methane is attributed to biomass burning and rice cultivation in the tropics [53-55]. The carbon dioxide increase is more difficult to ascribe to human activity, but Ruddiman argues that deforestation and biomass burning may be a primary factor [53-55]. The decrease in the spatial extent of forests beginning approximately 7000 years BP and at 5000 years BP may be related to early agrticultural activity [53-55] including forest clearance through burning which should leave a quantifiable signal in climate proxies.

The links between biomass burning and increased agriculture (and therefore increased GHGs including carbon dioxide and methane) and the prolongation of interglacial climate are only valid if measured increases in burning demonstrate a quantifiable relationship with increased temperature. Isotopic $\left(\delta^{13} \mathrm{C}\right)$ data suggests that the increase in carbon dioxide over the past 7000 years may be caused by natural changes in the carbon cycle [56]. Changes in the land biosphere may be insufficient to cause the Holocene carbon dioxide rise but may also necessitate changes in the marine-carbonate cycle [56-58]. It is difficult to ascribe late-Holocene methane concentrations to purely natural causes as Antarctic and Greenland ice core data show that the methane rise came from the tropics [14] where human activity may have had a pivotal role. The hypothesis of a detectable early human impact on climate directly relies on biomass burning as the cause of an increase in GHG concentrations. However, it is unknown if fire activity increased $\sim 7000$ and $\sim 5000$ years ago. Lake and ice cores can quantify the amount of biomass burning $\sim 7000$ and $\sim 5000$ years before present to determine if and how humans have been affecting the climate system for thousands of years.

Understanding of the role of biomass burning and agriculture in climate-fire feedbacks has important implications for the future. Deforestation fires significantly contribute to the atmospheric carbon dioxide concentration which creates a positive feedback loop as the associated warming increases extreme fire weather [7]. Currently, deforestation fires for agriculture supply up to $\sim 19 \%$ of the total modern increases in radiative forcing $[2,14]$. This anthropogenic alteration of the atmosphere has no parallel in the past, yet humans may have altered the climate system through past biomass burning. Determining if fire increased $\sim 7000$ and $\sim 5000$ through the use of pyrochemical ice and lake core records has the potential to quantify human impacts on the climate system for thousands of years as well as to provide essential insight into the role of atmospheric aerosols under a warming climate. 


\section{Conclusion}

Integrating multiple tracers of biomass burning and multiple matrices can provide essential information on past fire regimes on all continents. Molecular markers in ice and lake cores combine geochemical data and provide insight into when past fires occurred, the type of material burned, and the impacts of human activity. Levoglucosan is a specific molecular marker present in both ice and lake cores, and presence of levoglucosan in an environmental matrix is directly linked to woody tissue burning at temperatures greater than $300^{\circ} \mathrm{C}$. Supplementing levoglucosan flux measurements with other pyrochemical markers results in a more robust and nuanced understanding of past fire regimes. Compiling multiple paleofire indicators also reduces the possibility of incorrectly interpreting past fire history, as the possible atmospheric degradation of one material may be balanced by the presence of another paleofire marker which is stable under the same conditions. As pyrochemical and climate parameters are measured from the same depth within their respective ice or sediment matrix, the multi-proxy nature of ice and lake cores presents an ideal material to investigate the links between fires and climate change. Combining high-elevation and polar ice core sites with low to mid-elevation lake can demonstrate feedbacks between fire and climate across local, regional, and hemispheric scales. The global array of ice and lake cores contributes high-resolution Quaternary proxy records that provide a nearly-continuous record of climate parameters.

This study is a contribution to the Marie-Curie Incoming International Fellowship Project (PIIF-GA-2009236961 - PaleoFire), the ERC Advance Grant - EARLYhumanIMPACT (ERC AG-2010-267696) and the Past4Future project (grant number 243908) funded by the European Commission's 7th Framework Programme. It is Past4Future contribution number 1 and EARLYhumanIMPACT contribution number 1.

\section{References}

1. M.J. Power and 83 others, (2008) Clim. Dynam. 30, 887-907 (2008)

2. D. Bowman and 20 others, Science 324, 481-484 (2009)

3. J.R. Marlon and 21 others, PNAS 106, 8, 2519-2524 (2009)

4. S.G. Haberle, M.P. Ledru, Quat. Res. 55, 97-104 (2001)

5. C. Carcaillet and 21 others, Chemosphere 49, 845-863 (2002)

6. A.L.Westerling, H.G. Hidalgo, D.R. Cayan, T.W. Swetnam, Science 343, 940-943 (2006)

7. T.W. Swetnam, Science 262, 885-889 (1993)

8. G.H. Miller, M.L. Fogel, J.W. Magee, M.K. Gagan, S.J. Clarke, B.J. Johnson, Science, 309, 287-290 (2005)

9. G. Miehe, S. Miehe, K. Kaiser, C. Reudenbach, L. Behrendes, L. Duo, F. Schultz, Palaeogeog. Palaeoclim. Palaeoecol. 276, 1-4, 130-147 (2009)

10. J.L. Jimenez and 63 others, Science 326, 1525-1529 (2009)

11. Q. Zhang and 34 others, Geophys. Res. Lett. 34 L13801 (2007)

12. D. M Murphy, J. Geophys Res. 111, D23532 (2006)

13. S. Soloman, D. Qin, M. Manning, M. Marquis, K. Averyt, M.M.B. Tignor, H.L. Miller Jr., Z. Chen, IPCC Report 2007: The Physical Science Basis (Cambridge Univ. Press, 2007)

14. E. J. Brook, Nat. Geosci. 2, 170-172 (2009)

15. C. Barbante, C. Boutron, C. morel, C. Ferrari, J.L. Jaffezo, G. Cozzi, V. Gaspari, P. Cescon, J. Env. Monit. 5, 328-335 (2003)

16. A. Gambaro, R. Zangrando, P. Gabrielli, C. Barbante, P. Cescon, Anal. Chem. 80, 1649-1655 (2008)

17. J. Gabrieli, F. Decet, A. Luchetta, M. Valt, P. Pastore, C. Barbante, Environ. Poll. 158, 3130-3137 (2010)

18. M. Conedera, W. Tinner, C. Neff, M. Meurer, A.F. Dickens, P. Krebs, Quaternary Sci. Rev. 28, 555-576 (2008)

19. R.A. Hites, R.E. Laflamme, J.G. Windsor Jr., J.W. Farrington, W.G. Deuser, Geochem. Cosmochem. Acta, 446 873-878 (1980) 
20. M. Radzi bin Abas, D.R. Oros, B.R Simoneit, Chemosphere 55, 1089-1095 (2004)

21. T.B. Jordan, A. J. Seen, G.E. Jacobsen, Atmos Env. 40, 5316-5321 (2006)

22. B.R.T. Simoneit, App. Geochem, 17, 3, 129-162 (2002)

23. H.B. Locker, PhD Dissertation, Dartmouth College, Hanover, NH, USA (1988)

24. M.P. Fraser, K. Lakshmanan, Environ. Sci. Technol. 34, 4560-4564 (2000)

25. B.R.T. Simonei, M. Kobayashi, M. Mochida, K. Kawamura, B.J. Huebert, J. Geophys. Res. 109, D19, doi: D19s0910. 1029/2004jd004565 (2009)

26. B.J. Holmes, G.A. Petrucci, Environ. Sci. Technol. 40, 4983-1989 (2006)

27. B.J. Holmes, G.A. Petrucci, J. Atmos. Chem 58, 151-166 (2007)

28. S. Saarikoski, H. Timonen, K. Saarino, M. Aurela, L. Jarvi, P. Keronen, V.M. Kerminen, R. Hillamo, Atmos, Chem, Phys. 8, 6281-6295 (2008)

29. A.L. Robinson, R. Subramanian, N.M. Donahue, A. Bernardo-Bricker, W.F. Rogge, Environ. Sci. Tech. 40, 7811-7819 (2006)

30. D. Koch, G.A. Schmidt, C. Field, J. Geophys. Res. 111, D6 (2006)

31. T.M. Jenk, S. Szidat, M. Schwikowski, H.W. Gaeggler, L. Wacker, H.-A. Synal, M. Asurer, Nuc. Instr. Methods Phys. Res B. 259 (2997) 518-525 (2007)

32. J.F. Slater, L.A. Currie, J.E. Dibb, B.A. Benner Jr., Atmos Env. 36, 4463-4477 (2002)

33. D.G. Streets, T.C. Bond, G.R. Carmichael, S.D. Fernandes, Q. Fu, D. He, Z. Klimont, S.M. Nelson, N.Y. Tsai, M. Q.Wang, J-H. Woo, K. F. Yarber, J. Geophys. Res. 108, 8809, doi:10.1029/2002JD003093 (2003)

34. U.S. Environmental Protection Agency. Priority Pollutants; EPA: Washington, DC (2009)

35. J.L. Jaffrezo, M.P. Clain, P. Masclet, Atmos. Environ. 28, 1139-1145 (1994)

36. P. Masclet, V. Hoyau, J.L. Jaffrezo, H. Cachier, Atmos. Environ. 34, 3195-3207 (2000)

37. J. Ming, H. Cachier, C. Xiao, D. Qin, S. Kang, S. Hou, J. Xu, Atmos. Chem. Phys. 8, 1343-1452 (2008)

38. M. Legrand, M. De Angelis, J. Geophys. Res. 101, D2, 4129-4145 (1996)

39. M. Legrand, C. Saigne, Atmos. Environ. 22, 1011-1017 (1988)

40. M. Legrand, M. DeAngelis, J. Geophys. Res. 100, 1445-1462 (1995)

41. S. Hellman, M.J. Buntin, M.-J. Gaillard, Rev. Palaeobot. Palynol. 25, 3 245-258 (2009)

42. F. Thevenon, D. Williamson, E. Bard, F.S. Anselmetti, Beaufort, H. Cachier, Global and Plan. Change 72, 381-389 (2010)

43. W. Tinner, A.F. Lotter, B. Ammann, M. Conedera, P. Hubschmid, J.F.N. can Leeuwen, M. Wehrli, Qust. Sci. Rec. 22, 1447-1460 (2003)

44. M. Magny, J.N. Haas, J. of Quat. Sci. 19, 5, 423-430 (2004)

45. B. Mapunda, S. Burg, Nyame Akuma 36, 32-39 (1991)

46. C. Barbante and 87 others (EPICA community members), Nature, 444, 7116, 195-198 (2006)

47. J. Savarino, M. Legrand, J. Geophys. Res. 103, D7, 8267-8279 (1998)

48. A. Eicher, S. Bruetsch, S. Olivier, T. Papina, M. Schwikowski, Geophys. Res. Lett. 36, L18813 (2009)

49. T. Kellerhals, S. Bruetsch, M. Sigl, S. Knuesel, H.W. Gaeggler, M. Schwikowski, J. Gephys. Res. 115, D16123 (2010)

50. T. Kekonen, J.C. Moore, R. Mulvaney, E. Isaksson, V. Pohjola, R. S.W. Van de Wal, Anal. Glac. 35, 261- 265 (2002)

51. J.R. McConnell, R. Edwards, G.L. Kok, M.G. Flanner, C.S. Zender, E.S. Saltzman, J.R. Banta, D.R. Pasteris, M.M. Carter, J.D.W. Kahl, Science 371, 1381-1384 (2007)

52. V. Ramanathan, G. Charmichael, Nature Geosci. 1, 221-227 (2008)

53. W.F. Ruddiman, Climatic Change 61, 261-293 (2003)

54. S.Vavrus, W.F. Ruddiman, J.E. Kutzbach (2008) Quaternary Sci. Rev. 27, 1410-1425 (2008)

55. W.F. Ruddiman, Rev. Geophys. 45, 3, RG4001 (2007)

56. W. Broecker, T. Stocker, Eos 87 (3) 17 January (2006)

57. J. Elsig, J. Schmitt, D. Leuenberger, R. Schneider, M. Eyer, M. Leuenberger, F. Joos, H. Fischer, T.G. Stocker et al., Nature 461, 501-510 (2009)

58. F. Joos, S. Gerber, I.C. Prentice, B.L. Otto-Bliesner, P.J. Valdes, Global Biogeoch. Cycles 18, 2 (2004) 